$\begin{array}{lccccccrr}\text { Volume } & 13, \quad \text { Nomor } & 2, \quad \text { November } & \text { 2021, } & \text { pp } & \text { 388-401 } & \text { Copyright } & \text { C } & 2017 \\ \text { Jurnal } & \text { Akuntansi, } & \text { Program } & \text { Studi } & \text { Akuntansi, } & \text { Fakultas } & \text { Bisnis, } \\ \text { Universitas } & \text { Kristen } & \text { Maranatha } & \text { ISSN } & 2085-8698 & \text { e-ISSN } & 2598-4977 .\end{array}$

http://journal.maranatha.edu

\title{
Pengaruh Aset Tidak Berwujud, Ukuran Perusahaan, Kepatuhan Perpajakan, dan Leverage Terhadap Transfer Pricing
}

\author{
Ickhsanto Wahyudi ${ }^{1}$ \\ Universitas Esa Unggul \\ Jalan Arjuna Utara No.9, Kebon Jeruk, Jakarta \\ ickhsanto.wahyudi@esaunggul.ac.id \\ Nur Fitriah ${ }^{2}$ \\ Universitas Esa Unggul \\ Jalan Arjuna Utara No.9, Kebon Jeruk, Jakarta \\ nfitria.ueu106@gmail.com
}

\begin{abstract}
This study aims to determine the effect of intangible assets, firm size, tax compliance, leverage on transfer pricing. The data analysis uses multiple linear regressions on 12 manufacturing companies listed on the Indonesia Stock Exchange (IDX) during 2015-2019. The results of this study show that intangible assets, firm size, tax compliance, leverage simultaneously have a significant effect on a company's decision to practice transfer pricing, as well as intangible assets and leverage partially, have a positive and significant effect on transfer pricing. But firm size partly has a negative and significant effect on transfer pricing. Meanwhile, tax compliance has no significant effect on transfer pricing.
\end{abstract}

Keywords: Intangible Assets, Firm Size, Tax Compliance, Leverage, and Transfer Pricing

\begin{abstract}
Abstrak
Penelitian ini bertujuan untuk mengetahui pengaruh aset tidak berwujud, ukuran perusahaan, kepatuhan perpajakan, dan leverage terhadap transfer pricing. Analisis data menggunakan regresi linier berganda pada 12 perusahaan manufaktur yang terdaftar di Bursa Efek Indonesia (BEI) selama periode 2015-2019. Hasil penelitian ini menunjukkan bahwa aset tidak berwujud, ukuran perusahaan, kepatuhan perpajakan, dan leverage secara serempak berpengaruh signifikan terhadap keputusan perusahaan dalam melakukan praktik transfer pricing, serta aset tidak berwujud dan leverage secara parsial berpengaruh positif dan signifikan terhadap transfer pricing. Namun, ukuran perusahaan secara parsial berpengaruh
\end{abstract}


negatif dan signifikan terhadap transfer pricing. Sedangkan, kepatuhan perpajakan tidak berpengaruh signifikan terhadap transfer pricing.

\section{Kata Kunci: Aset Tidak Berwujud, Ukuran Perusahaan, Kepatuhan Perpajakan, Leverage, dan Transfer Pricing}

\section{Pendahuluan}

Globalisasi sangat berkontribusi pada perkembangan arus intragroup, membuat harga transfer menjadi strategis, baik untuk perusahaan multinasional dan otoritas pajak di seluruh dunia. Organisasi Kerja Sama dan Pembangunan Ekonomi (OECD) memprediksi total arus intragroup mewakili lebih dari $70 \%$ dari total perdagangan di seluruh dunia (Merle et al., 2019). Skandal terkait pajak yang dipublikasikan dalam beberapa tahun terakhir yang melibatkan beberapa perusahaan besar seperti Amazon, Google atau Starbucks (Barford \& Holt, 2013). Perusahaan-perusahaan ini dituduh melakukan penghindaran pajak pada skala industri dengan mengalihkan laba ke yurisdiksi pajak yang lebih rendah melalui skema transfer pricing.

Pada umumnya rencana yang dipakai perusahaan multinasional pada praktik transfer pricing yaitu mentransfer keuntungan mereka dari negara yang memungut pajak tinggi ke negara dengan pungutan pajak yang lebih rendah (Darussalam et al., 2013). Menurut Panduan Transfer Pricing Organisasi Kerja Sama \& Pembangunan Ekonomi (OECD) untuk Perusahaan Multinasional dan Administrasi Pajak (2010), transfer pricing berkaitan dengan nilai moneter yang melekat pada transaksi lintas batas antara pihak-pihak berelasi dari suatu grup yang terkonsolidasi tetapi didirikan di yurisdiksi yang berbeda.

Banyak perhatian telah difokuskan pada perusahaan multinasional, terutama ketika terdapat transaksi lintas batas yang berdasarkan pada aset tidak berwujud yang sulit diukur (Dyreng et al., 2017). Kesulitan tersebut disebabkan oleh pengukuran yang mengacu terhadap nilai pasar, dengan demikian penilaian yang dilakukan mempunyai sifat yang subjektif. Perusahaan bisa memanfaatkan secara bersamaan pada beberapa yurisdiksi dengan skema transfer pricing kepada tindakan yang oportunistik (Baldenius, 2006). Perusahaan dalam hal ini akan mengalokasikan aset tidak berwujud mereka ke negara rendah pajak menggunakan teknik transfer pricing. Dischinger \& Riedel (2011) mengatakan bahwa pengalokasian aset tidak berwujud dalam MNE terdistorsi ke afiliasi yang memiliki pajak lebih rendah.

Antara perusahaan dengan kegiatan perusahaan dan transaksi keuangan yang mempunyai perbandingan yang positif, apabila suatu perusahaan makin besar maka transaksi keuangan serta kegiatan perusahaan tersebut juga akan semakin besar, dan tentunya hal ini akan berdampak pada keuntungan yang bisa didapatkan oleh perusahaan. Ukuran perusahaan dapat mempengaruhi keputusan perusahaan dalam melaksanakan transfer pricing, karena ukuran perusahaan menunjukkan besar kecilnya nilai perusahaan. Besarnya aset yang dipunyai perusahaan menjadi gambaran mengenai prospek bisnis yang menjanjikan diwaktu yang akan datang (Cledy \& Amin, 2020). Ukuran perusahaan dianggap penting bagi investor sebab akan berkaitan langsung dengan risiko investasi. Perusahaan yang lebih besar cenderung memiliki pengelolaan laba yang kecil karena minimnya dorongan dalam melakukan pengelolaan laba, salah satunya yaitu transfer pricing (Kiswanto \& Purwaningsih, 2015).

Kepatuhan perusahaan untuk melaksanakan kewajiban perpajakannya 
merupakan poin penting dalam meningkatkan penerimaan negara dari sektor pajak. Melalui pajak pembangunan negara dapat terlaksana guna kesejahteraan masyarakat. Pemungutan pajak tidak mudah diterapkan, terutama bagi perusahaan yang mempunyai anggapan bahwa pajak merupakan beban yang dapat mengurangi keuntungan perusahaan (Arianandini \& Ramantha, 2018). Tingginya beban pajak yang diterima perusahaan akan berpotensi terhadap perusahaan tersebut untuk mengalihkan keuntungan melalui transfer pricing. Menchaoui, Rossignol, \& Omri (2017) menyimpulkan bahwa keputusan penetapan transfer pricing digunakan untuk memaksimalkan keuntungan dan meminimalkan pajak global.

Indikasi lainnya yang dilakukan perusahaan dalam upaya memperkecil pajak penghasilan terutangnya dapat dilihat dari kebijakan pendanaan yang diterapkan salah satunya melalui leverage. Menurut Richardson, Hanlon, \& Nethercott (1998) perusahaan multinasional biasanya membiayai anggota kelompok dengan mentransfer utang dan/atau modalnya yang dimotivasi oleh peluang dalam mengarbitrase pajaknya. Sehingga perusahaan yang mempunyai keterlibatan dengan hal tersebut memiliki kesempatan lebih besar untuk mempraktikkan transfer pricing. Menurut Richardson \& Lanis (2007) memberikan penjelasan bahwa semakin banyak perusahaan yang membiayai dirinya sendiri dengan hutang, maka semakin rendah beban pajaknya. Hal tersebut dibuktikan kembali oleh Taylor, Richardson, \& Lanis (2015) bahwa pembiayaan utang memiliki hubungan positif dengan penghindaran pajak.

Namun demikian, penelitian terdahulu mengenai aset tidak berwujud, ukuran perusahaan, effective tax ratio, dan leverage sudah dilakukan (Merle et al., 2019), adapun yang membedakan dengan penelitian sebelumnya ialah objeknya menggunakan perusahaan yang terdaftar di indeks CAC-40 bursa saham Perancis periode 2012-2015. Penelitian ini menggunakan perusahaan manufaktur yang terdaftar di Bursa Efek Indonesia periode 2015-2019, dengan alasan karena praktik transfer pricing banyak terjadi pada perusahaan manufaktur multinasional yang memiliki anak atau cabang di luar negeri (Arianandini \& Ramantha, 2018).

Penelitian dilakukan untuk mengetahui tentang seberapa besar pengaruh aset tidak berwujud, ukuran perusahaan, kepatuhan perpajakan, dan leverage terhadap praktik transfer pricing pada perusahaan manufaktur yang terdaftar di Bursa Efek Indonesia periode 2015-2019. Melalui penelitian ini diharapkan bisa menjadi bahan pertimbangan pada implementasi kebijakan transfer pricing dalam perusahaan dan dapat memberi gambaran bagi pengguna laporan keuangan untuk berhati-hati dan cermat ketika menganalisa informasi keuangan.

\section{Kerangka Teoritis dan Hipotesis}

\section{Teori Keagenan (Agency Theory)}

Jensen \& Meckling (1976) memberikan penjelasan terkait dengan teori keagenan, yakni sebuah hubungan yang terjadi antara prinsipal selaku pihak yang memberikan tugas kepada agen untuk mengerjakan kepentingan principal tersebut dengan agen selaku pihak yang diberikan tugas oleh pihak prinsipal. Salah satu agen adalah manajer, sebagai agen memiliki tanggung jawab moral untuk memaksimalkan perolehan laba bagi pemilik serta bisa mendapatkan imbalan sesuai kontrak. Sehingga hal ini memunculkan dua kepentingan berbeda, dimana semua pihak senantiasa berusaha dalam memperoleh serta mempertahankan kemakmurannya masing-masing (Scott, 2000).

Hubungan teori keagenan dengan transfer pricing menurut Indriaswari \& Aprilia (2017) adalah bahwa setiap individu cenderung akan mementingkan dirinya sendiri yang menyebabkan munculnya masalah-masalah keagenan 
karena kepentingannya yang berbeda, meskipun begitu dalam pekerjaannya masing-masing pihak mempunyai tugas berbeda satu sama lainnya sehingga bisa melakukan kerja sama. Permasalahan keagenan ini bisa berdampak pada kerugian prinsipal yang memiliki batas keterlibatan untuk mengelola perusahaan, dengan demikian prinsipal tidak memperoleh informasi yang memadai. Kewenangan yang agen miliki membuat mereka mengesampingkan shareholder melalui pemanfaatan insentif untuk tujuan menurunkan beban pajaknya dengan melakukan praktik transfer pricing (Cledy \& Amin, 2020).

\section{Transfer Pricing}

Transfer pricing menurut Horngren, Sratton, \& Sundem (1996) dapat digunakan sebagai instrumen yang bisa digunakan dalam memaksimalkan keuntungan dengan menentukan harga produk atau jasa oleh unit organisasi lain yang masih dalam satu perusahaan (Intra-company Transfer Pricing). Namun, transfer pricing berkembang sehingga dalam praktiknya bukan saja melibatkan dalam satu perusahaan, namun adanya kontribusi dari perusahaan multinasional (Inter-company Transfer Pricing).

Arm's length principle (ALP) merupakanpilar penting pada pengalokasian keuntungan dalam prinsip pajak internasional, hal ini mensyaratkan bahwa dalam bertransaksi dengan pihak berelasi, nilai transaksi harus setara dengan nilai transaksi dengan pihak yang tidak berelasi, sehingga tidak menyebabkan adanya diskriminasi atas harga transfer di antara keduanya (OECD, 2010). Namun praktiknya, terdapat manipulasi transfer pricing yang merupakan penetapan harga transfer menjadi tidak wajar dengan menaikkan maupun menurunkan harga dengan maksud memperkecil jumlah pajak terutangnya. Hal tersebutlah yang mengindikasi adanya praktik transfer pricing (Darussalam et al., 2013).

\section{Aset Tidak Berwujud}

OECD (OECD, 2010) menerangkan bahwa aset tidak berwujud didefinisikan sebagai sesuatu yang tidak memiliki bentuk fisik, tetapi dapat dimiliki dan dikendalikan dengan maksud penggunaan di masa depan dalam kegiatan komersial perusahaan. Aset tidak berwujud merupakan salah satu isu yang cukup besar dalam transaksi pihak berelasi dari MNE. Mereka secara strategis dapat mendistribusikan aset tidak berwujudnya kepada anggotanya di yurisdiksi pajak rendah, selanjutnya mereka bisa melakukan penerimaan atas pembayaran royalti yang berasal dari afiliasi yang berlokasi di negara-negara dengan pajak tinggi (Dudar et al., 2015). Kusuma \& Wijaya menambahkan (2017), karena aset tidak berwujud tidak memiliki pasar yang mapan tetapi penilaian subjektif, perusahaan-perusahaan ini juga dapat mengeksploitasi secara bersamaan di beberapa yurisdiksi melalui mekanisme transfer pricing. Dengan kata lain, aset tidak berwujud dapat digunakan untuk mengalihkan keuntungan antara perusahaan afiliasi dengan tujuan meminimalkan kewajiban pajak global dari grup multinasional.

\section{Ukuran Perusahaan}

Jensen \& Meckling (Jensen \& Meckling, 1976) menerangkan biaya keagenan yang besar berbanding lurus dengan ukuran perusahaannya. Dalam hal ini, ukuran perusahaan diartikan dengan suatu perbandingan kecil atau besarnya perusahaan berdasarkan cara-cara tertentu, diantaranya yaitu jumlah seluruh aset, penjualan, serta nilai pasar saham. Ukuran perusahaan juga merupakan salah satu faktor yang bisa mempengaruhi persepsi investor dan calon investor mengenai perusahaan tersebut. Apabila perusahaan semakin besar, maka semakin kompleks sistem manajemen yang dimiliki, begitu pula dengan laba yang dihasilkan. Besarnya perusahaan memperlihatkan bahwa perusahaan berkembang secara positif, hal 
itu akan menarik perhatian orang yang akan melakukan investasi dan memungkinkan adanya respon positif terhadap perusahaan (Hery, 2017). Salah satu tolak ukur ukuran perusahaan dapat dilihat dari nilai asetnya. Apabila perusahaan mempunyai nilai aset yang besar, maka hal tersebut mengindikasi perusahaan mempunyai prospek positif, karena menggambarkan perusahaan lebih mampu untuk menghasilkan laba yang besar (Putri \& Putra, 2017).

\section{Kepatuhan Pajak}

Kepatuhan perusahaan untuk melaksanakan kewajiban perpajakannya merupakan poin penting dalam meningkatkan penerimaan negara dari sektor pajak. Kepatuhan yaitu kepatuhan pada otoritas dan aturan, sedangkan kepatuhan perpajakan yaitu suatu tolak ukur bagi wajib pajak orang pribadi maupun badan mematuhi undang- undang dan administrasi perpajakan tanpa diperlukannya penegakan hukum (Chaizi, 2014). Kondisi sistem administrasi perpajakan suatu negara, pelayanan pada wajib pajak, penegakan hukum perpajakan, pemeriksaan pajak, dan tarif pajak merupakan beberapa faktor yang mempengaruhi kepatuhan perpajakan. Kepatuhan perpajakan memiliki karakteristik, yaitu membayar besarannya pajak terutang sesuai nominal, memahami dan mematuhi semua hak dan kewajibannya dalam bidang perpajakan, serta mematuhi kriteria-kriteria tertentu (Supriyanti \& Hidayati, 2008).

\section{Leverage}

Kasmir (2008) menjelaskan leverage sebagai alat ukur yang bisa dipakai dalam memperoleh informasi tentang seberapa jauh aset perusahaan yang biayanya diperoleh dari hutang, serta untuk mengetahui kemampuan perusahaan dalam membayarkan kewajibannya dalam jangka waktu tertentu. Hutang dapat menghancurkan perusahaan pada saat kesulitan keuangan dan dapat menyebabkan kehancuran keuangan. Hutang dianggap sebagai instrumen keuangan yang berbahaya kecuali jika dikelola dengan baik dengan moderasi yang hati-hati (McConnell \& Servaes, 1995).

Teori akuntansi positif mempunyai asumsi bahwasannya manajer bekerja secara rasional, sehingga memiliki kecenderungan dalam pemilihan kebijakan akuntansi paling sesuai kepentingannya (Firmansyah \& Yunidar, 2020). Richardson, Taylor, \& Lanis (2013) menyatakan bahwa leverage merupakan salah satu variabel yang berpengaruh positif terhadap praktik transfer pricing. Semakin tinggi leverage berarti tanggungan terhadap pajak semakin sedikit, dengan demikian berhutang mejadi pilihan bagi manajemen meminimalisir beban pajak.

\section{Hubungan Aset Tidak Berwujud dan Transfer Pricing}

Dalam Pedoman Penetapan Transfer Pricing (OECD, 2010), OECD menyebutkan properti yang tidak memiliki wujud memanfaatkan aset industri misalnyamerek, hak paten, kekayaan intelektual, rahasia industri dan bisnis, desain danmodel. Dalam ekonomi berbasis inovasi, sebagian besar nilai perusahaan didasarkan pada aset tidak berwujud yang mengarahpada keunggulan kompetitif. Jenis aset berharga yang mudah ditransfer dapat mengarah ke tax planning dan meningkatkan masalah transfer pricing. Beberapa perusahaan multinasional bisa melakukan pengalokasian aset tidak memiliki wujud ke yurisdiksi pajak lebih rendah, menghasilkan royalti atau biaya lisensi dari entitas perusahaan di negara dengan pajak lebih tinggi yang mendapatkan keuntungan dari aset tersebut yang memungkinkan adanya peralihan laba (Merle et al., 2019). Dischinger \& Riedel (Dischinger \& Riedel, 2011) membuktikan secara empiris bahwa pengalokasian aset tidak berwujud dalam MNE terdistorsi ke afiliasi yang memiliki pajak lebih rendah. 
MNE mungkin melebih-lebihkan harga transfer untuk mengalihkan keuntungan dari afiliasi dengan pajak tinggi ke afiliasi pemegang aset tidak berwujud di negara dengan pajak rendah. Berdasarkan uraian di atas, maka dirumuskan hipotesis berikut:

H1: Aset tidak berwujud berpengaruh positif terhadap transfer pricing.

\section{Hubungan Ukuran Perusahaan dan Transfer Pricing}

Merle, Al-Gamrh, \& Ahsan (Merle et al., 2019) menerangkan bahwa ukuran perusahaan merupakan kombinasi dari beberapa faktor seperti jumlah karyawan, jumlah penjualan, jumlah anak perusahaan, profitabilitas, kapasitas produksi, intensitas modal, dan penilaian saham. Perusahaan besar cenderung mempunyai diversifikasi produk yang dapat mendorong penggunaan kebijakan transfer pricing. Penggunaan tersebut dimaksudkan untuk memaksimalkan keuntukan dan meminimalkan pajak terutang perusahaan. Perusahaan dengan skala besar cenderung memiliki pengelolaan laba yang kecil karena minimnya dorongan dalam melakukan pengelolaan laba dibandingkan dengan perusahaan dengan skala kecil, karena perusahaan besar dianggap lebih kritis oleh pihak investor terutama yang berkaitan langsung dengan risiko investasi (Kiswanto \& Purwaningsih, 2015). Pernyataan lain dikuatkan kembali oleh Kusumasari, Fadilah, \& Sukarmanto (2018) bahwa ukuran perusahaan berpengaruh negatif terhadap transfer pricing. Berdasarkan uraian di atas, maka dirumuskan hipotesis berikut:

$\mathrm{H} 2$ : Ukuran Perusahaan berpengaruh negatif terhadap transfer pricing

\section{Hubungan Kepatuhan Perpajakan dan Transfer Pricing}

Suatu kelompok yang terkonsolidasi harus mempertimbangkan perbedaan tarif pajak di setiap yurisdiksi tempat mereka melakukan kegiatan ekonomi, oleh karena itu terdapat perbedaan antara strategi global yang akan diterapkan dan strategi perpajakan lokalnya. Dampak pajak dapat diukur dengan menghitung tarif pajak efektif (ETR) yang dapat memberikan informasi apakah MNE menggunakan teknik penghindaran pajak untuk meminimalkan beban pajaknya atau tidak ((Merle et al., 2019). Menchaoui, Rossignol, \& Omri (Menchaoui et al.,2017) yang membuktikan bahwa transaksi antara pihak berelasi mempunyai tarif pajak berbeda yang berpeluang cukup besar untuk melakukan praktik manajemen fiskal. Jadi keputusan penetapan transfer pricing digunakan untuk memaksimalkan keuntungan dan meminimalkan pajak global. Berdasarkan uraian di atas, maka dirumuskan hipotesis berikut:

H3: Kepatuhan Perpajakan berpengaruh negatif terhadap transfer pricing

Hubungan Leverage dan Transfer Pricing Menurut Modigliani \& Miller (1958), dalam situasi pasar modal sempurna, nilai perusahaan dipengaruhi oleh treasury flows dari aset perusahaan, bukan struktur keuangannya. Dengan adanya pajak, hal tersebut digambarkan dengan nilai perusahaan yang leverage-nya melebihi nilai perusahaan, yang tidak memiliki leverage diperbolehkan melakukan penghematan pajak melalui pengurangan pajak atas bunga. Berdasarkan teori keagenan, situasinya adalah di mana prinsipal (otoritas pajak) ingin menarik pendapatan sebanyak mungkin dan agen (korporasi) sebaliknya, ingin menurunkan beban pajaknya (Fama, 1980). Oleh karena itu, leverage dapat digunakan untuk mengurangi pajak yang dibayarkan melalui biaya bunga yang tinggi, laba yang lebih rendah, dan ETR yang lebih rendah (Merle et al., 2019). Richardson \& Lanis (Richardson \& Lanis, 2007) dinyatakan bahwa semakin banyak perusahaan yang membiayai dirinya sendiri dengan hutang, maka semakin rendah beban pajaknya. Pernyataan lain dipertegas oleh Taylor, Richardson, \& Lanis (Taylor et al., 2015) yang membuktikan secara empiris bahwa pembiayaan hutang memiliki 
hubungan positif dengan penghindaran pajak. Berdasarkan uraian di atas, maka dirumuskan hipotesis berikut:

$\mathrm{H} 4$ : Leverage berpengaruh positif terhadap transfer pricing.

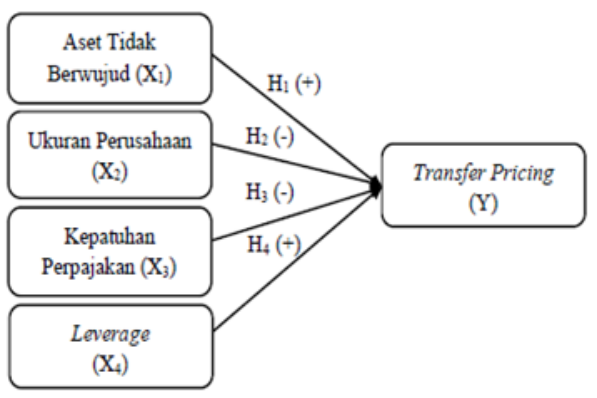

\section{Gambar 1 Model Penelitian}

\section{Metode Penelitian}

Desain penelitian yang digunakan adalah kausalitas yaitu untuk mengetahui hubungan antara sebab dan akibat dari variabelvariabel yang diteliti. Jenis data yang digunakan pada penelitian ini adalah data kuantitatif, sumber data yang digunakan adalah data sekunder berupa laporan keuangan perusahaan manufaktur yang terdaftar di BEI periode 2015-2019. Data diperoleh dari www.idx.co.id dengan waktu penelitian pada Oktober 2020 hingga Mei 2021.

Populasi yang dianalisis dalam penelitian ini adalah perusahaan manufaktur yang terdaftar di BEI periode 2015-2019. Teknik pemilihan sampel menggunakan purposive sampling. Sampel awal mencakup semua perusahaan manufaktur yang tidak mengalami delisting di BEI dan menerbitkan laporan keuangan lengkap. Namun, untuk memenuhi kriteria perusahaan multinasional dan membuktikan adanya hubungan istimewa, maka beberapa perusahaan dikeluarkan dari sampel, termasuk bagi perusahaan yang tidak melaporkan nilai aset tidak berwujud dalam laporan keuangannya. Perusahaan yang mengalami kerugian selama 5 tahun terakhir juga telah dihapus dari sampel karena bagi perusahaan yang mengalami kerugian tidak diharuskan membayar pajak, sehingga akan tidak relevan apabila perusahaan yang mengalami kerugian dimasukkan dalam sampel penelitian ini. Dengan demikian, sampel akhir terdiri dari 12 perusahaan manufaktur selama periode 5 tahun dengan total 60 laporan keuangan.

Transfer pricing diukur dengan membagi piutang transaksi pihak berelasi (RPT) dengan total piutang, aset tidak berwujud diukur dengan Ln (Intangible Assets), ukuran perusahaan diukur dengan Ln (Total Assets), kepatuhan perpajakan diukur dengan membagi beban pajak dan laba sebelum pajaknya (ETR), leverage diukur dengan membagi total kewajiban dan total ekuitas (DER). Analisis data penelitian ini menggunakan statistik deskriptif, uji asumsi klasik, analisis regresi linier berganda, uji hipotesis dan uji koefisien determinasi (R2).

\section{Hasil Penelitian dan Pembahasan}

\section{Tabel 1}

Statistik Deskriptif

\begin{tabular}{|c|r|r|r|c|}
\hline \multicolumn{5}{|c|}{ Descriptive Statistics } \\
\hline & Min & \multicolumn{1}{|c|}{ Max } & \multicolumn{1}{c|}{ Mean } & $\begin{array}{c}\text { Std. } \\
\text { Dev }\end{array}$ \\
\hline$Y$ & 0.00003 & 0.73987 & 0.21469 & 0.20533 \\
\hline $\mathrm{X}_{1}$ & 1.855 .141 & 2.951 .881 & 2.501 .316 & 284.195 \\
\hline $\mathrm{X}_{2}$ & 2.754 .928 & 32.20096 & 2.975 .253 & 145.962 \\
\hline $\mathrm{X}_{3}$ & 0.10162 & 0.58087 & 0.29111 & 0.07666 \\
\hline$X_{4}$ & 0.18724 & 432.626 & 0.94004 & 0.71448 \\
\hline
\end{tabular}

Statistik deskriptif menunjukkan hasil olah data uji statistik deskriptif yang memuat informasi berupa nilai minimum, maksimum, mean, dan standard deviation dari masing-masing variabel. Variabel transfer pricing dari 60 sampel memiliki nilai tertinggi sejumlah 0,73987 yang dimiliki Indofood CBP Sukses Makmur Tbk tahun 2016 dan nilai terendah sejumlah 0,00003 yang dimiliki Argha Karya Prima 
Ind. Tbk tahun 2019 dengan nilai rata-rata 0,21469 dan dengan standard deviation 0,20533 . Variabel aset tidak berwujud dari 60 sampel memiliki nilai tertinggi sejumlah 29,51881 yang dimiliki Indofood Sukses Makmur Tbk tahun 2015 dan nilai terendah sejumlah 18,55141 yang dimiliki Panca Budi Idaman Tbk tahun 2015 dengan nilai ratarata 25,01316 dan dengan standard deviation 2,84195. Kemudian, variabel ukuran perusahaan dari 60 sampel memiliki nilai tertinggi sejumlah 32,20096 yang dimiliki Indofood Sukses Makmur Tbk tahun 2018 dan nilai terendah sejumlah 27,54928 yang dimiliki Panca Budi Idaman Tbk tahun 2015 dengan nilai rata-rata 29,75253 dan dengan standard deviation 1,45962. Sementara, variabel kepatuhan perpajakan dari 60 sampel memilikil nilai tertinggi sejumlah 0,58087 yang dimiliki Argha Karya Prima Ind. Tbk tahun 2017 dan nilai terendah sejumlah 0,10162 yang dimiliki Impack Pratama Industri Tbk tahun 2018 dengan nilai rata-rata 0,29111 dan dengan standard deviation 0,07666. Dan, variabel Leverage dari 60 sampel memiliki nilai tertinggi sejumlah 4,32626 yang dimiliki Panca Budi Idaman Tbk tahun 2015 dan nilai terendah sejumlah 0,18724 yang dimiliki HM Sampoerna Tbk tahun 2015 dengan nilai rata-rata 0,94004 dan dengan standard deviation 0,71448 .

Hasil uji asumsi klasik menunjukkan data terdistribusi secara normal dan tidak terjadi multikolinearitas, heteroskedastisitas, dan autokorelasi. Sebelumnya autokorelasi dilakukan dengan uji Durbin Watson (DW), namun hasil menunjukkan nilai DW terletak di antara nilai dL dan dU yang artinya tidak ada kesimpulan pasti tentang terjadi atau tidaknya gejala autokorelasi. Masalah tersebut kemudian dilakukan dengan uji runtest yang mendapatkan nilai Sig adalah 0,298 sehingga dapat disimpulkan bahwa data terbebas dari gejala autokorelasi.

Hasil uji analisis regresi menunjukkan nilai konstanta sebesar -1,223 artinya apabila variabel independennya 0 , maka praktik transfer pricing menurun sejumlah 1,223.
Nilai koefisien regresi aset tidak berwujud (X1) sejumlah 0,801, sehingga dapat diartikan apabila variabel independennya tetap dan variabel aset tidak berwujud mengalami kenaikan 1\%, maka transfer pricing akan meningkat sejumlah 0,801 . Nilai koefisien regresi ukuran perusahaan (X2) sejumlah -0,701, sehingga dapat diartikan apabila variabel independennya tetap dan variabel ukuran perusahaan mengalami kenaikan 1\%, maka transfer pricing akan menurun sejumlah 0,701 . Nilai koefisien regresi kepatuhan perpajakan (X3) sejumlah $-4,177$, sehingga dapat diartikan apabila variabel independennya tetap dan variabel kepatuhan perpajakan mengalami kenaikan $1 \%$, maka transfer pricing akan menurun sejumlah 4,177. Serta, nilai koefisien regresi leverage (X4) sejumlah 0,904, sehingga dapat diartikan apabila variabel independennya tetap dan variabel leverage mengalami kenaikan $1 \%$, maka transfer pricing akan meningkat sejumlah 0,904 .

Hasil uji $\mathrm{F}$ (simultan) menunjukkan nilai sig adalah kurang dari 0,05 . Hal tersebut dapat disimpulkan bahwa model penelitian diterima dan variabel independen secara simultan berpengaruh signifikan terhadap variabel dependennya.

\section{Tabel 2}

Hasil Uji t

\begin{tabular}{|c|l|c|c|}
\hline & \multicolumn{2}{|c|}{ Nilai } & \\
\hline Hipotesis & B & Sig & Keterangan \\
\hline H1 & 0,801 & 0,000 & Diterima \\
\hline H2 & $-0,701$ & 0,002 & Diterima \\
\hline H3 & $-4,177$ & 0,155 & Ditolak \\
\hline H4 & 0,904 & 0,009 & Diterima \\
\hline
\end{tabular}

Hasil uji t (parsial) menunjukkan bahwa variabel aset tidak berwujud (X1) berpengaruh positif dan signifikan terhadap transfer pricing, maka H1 diterima. Hal tersebut ditunjukkan oleh nilai koefisien 0,801 dengan tingkat signifikansi $0,000<$ 0,05 . Variabel ukuran perusahaan (X2) 
berpengaruh negatif dan signifikan terhadap transfer pricing, maka $\mathrm{H} 2$ diterima. Hal tersebut ditunjukkan oleh nilai koefisien 0,701 dengan tingkat signifikansi $0,002<$ 0,05 . Namun, variabel kepatuhan perpajakan (X3) tidak berpengaruh terhadap transfer pricing yang mana nilai signifikansi 0,155 >0,05, maka H3 ditolak. Sedangkan, variabel leverage (X4) berpengaruh positif dan signifikan terhadap transfer pricing, maka $\mathrm{H} 4$ diterima. Hal tersebut ditunjukkan oleh nilai koefisien 0,904 dengan tingkat signifikansi $0,009<$ 0,05 .

Hasil uji koefisien determinasi (R2) menunjukkan nilai Adjusted $R$ Square adalah sebesar 0,496 atau 49,6\%. Hal tersebut menjelaskan bahwa variabel independen mempengaruhi variabel dependen sebesar 49,6\% dan sisanya sebesar $50,4 \%$ berasal dari variabel lain yang berada di luar model penelitian.

\section{Pengaruh Aset Tidak Berwujudterhadap Tansfer Pricing}

Aset tidak berwujud diproksikan dengan Ln (Intangible Assets) secara parsial berpengaruh positif terhadap transfer pricing. Sebagai mana penelitian yang pernah dilaksanakan Dischinger \& Riedel (Dischinger \& Riedel, 2011) yang membuktikan secara empiris bahwa pengalokasian aset tidak berwujud dalam MNE terdistorsi ke afiliasi yang memiliki pajak lebih rendah. MNE mungkin melebihlebihkan harga transfer untuk mengalihkan keuntungan dari afiliasi dengan pajak tinggi ke afiliasi pemegang aset tidak berwujud di negara dengan pajak rendah. Hasil serupa juga dikemukakan oleh Apriani, Putri, \& Umiyati (Apriani et al., 2020) dalam penelitiannya yang menyatakan bahwa aset tidak berwujud berpengaruh positif terhadap keputusan praktis transfer pricing perusahaan. Hal tersebut dipicu oleh risiko agresivitas transfer pricing yang meningkat karena adanya perbedaan dalam interpretasi penilaian harga transfer. Selain itu, perusahaan juga mengalami kesulitan dalam mendefinisikan dengan tepat transaksi mengenai aset tidak berwujud.

\section{Pengaruh Ukuran Perusahaan terhadap Transfer Pricing}

Ukuran perusahaan diproksikan dengan Ln (Total Assets) secara parsial berpengaruh negatif terhadap transfer pricing. Akan tetapi hasil ini berbeda terhadap apa yang ditemukan Rego (2003) dalam penelitiannya yang membuktikan bahwasanya ada hubungan yang positif antara ukuran perusahaan dengan beban pajak yang ditanggungnya. Dengan kata lain, perusahaan yang lebih besar cenderung melakukan pengalihan aset dan jasa pada skala yang lebih besar dan dengan demikian mendapatkan keuntungan lebih dari variasi pajak dan skala ekonomi. Namun sejalan dengan hasil penelitian ini, studi empiris oleh Kiswanto \& Purwaningsih (Kiswanto \& Purwaningsih, 2015) menyimpulkan bahwa perusahaan yang lebih besar mungkin mencoba untuk tidak terdorong untuk melakukan pengoptimalan tersebut karena perhatian otoritas pajak dan kemarahan publik yang dapat merugikan bisnis dan operasi mereka. Hasil dari hipotesis juga menunjukkan bahwa peluang perusahaan kecil dalam melakukan transfer pricing mungkin lebih besar karena ingin memperlihatkan kepada publik adanya kinerja yang baik dan memuaskan. Hasil serupa juga dikemukakan oleh Cledy \& Amin (Cledy \& Amin, 2020) ukuran perusahaan berpengaruh negatif dan tidak signifikan terhadap keputusan untuk melakukan transfer pricing. Dalam penelitiannya mengungkapkan jika semakin besar ukuran perusahaan tidak menjadi pendorong semakin tinggi transfer pricing yang diterapkan oleh perusahaan. Akan tetapi, perusahaan dengan aset kecil pun juga memungkinkan untuk melakukan transfer pricing dengan tujuan memperkecil beban pajak yang ditanggung perusahaan. 


\section{Pengaruh Kepatuhan Perpajakan terhadap Transfer Pricing}

Kepatuhan perpajakan diproksikan dengan Effective Tax Rate (ETR) tidak berpengaruh siginifikan terhadap transfer pricing. Hasil penelitian ini berbeda dengan hasil penelitian yang dilakukan Menchaoui, Rossignol, \& Omri (Menchaoui et al., 2017) yang membuktikan secara empiris bahwa transaksi antara pihak berelasi memiliki tarif pajak berbeda yang berpeluang cukup besar untuk melakukan praktik manajemen fiskal. Jadi keputusan penetapan transfer pricing dipakai dalam memaksimalkan keuntungan dan meminimalkan pajak global. Namun Khotimah (2018) dalam penelitian yang pernah dilakukannya mengatakan bahwasannya perusahaan yang memiliki beban pajak tinggi, pajak yang dibayarkan juga tinggi. Hal tersebut dalam rangka membantu pemerintah dalam mengoptimalkan pendapatan negara melalui pajak. Dengan hasil yang tidak signifikan dalam penelitian ini, memperlihatkan transfer pricing tidak dijadikan sebagai mekanisme untuk menghemat pajak bagi perusahaan. Tujuan perusahaan melakukan praktik transfer pricing tidak hanya meminimalisir pajak saja, melainkan juga alasan lainnya selain untuk mekanisme penghematan pajak. Hal serupa juga diungkapkan oleh Baiti \& Suryani (Baiti \& Suryani, 2020) yang menyatakan bahwa keputusan transfer pricing tidak dipengaruhi oleh effective tax rate secara parsial yang menunjukkan bahwa kemungkinan perusahaan mengurangi beban pajak adalah dengan menerapkan manajemen pajak dengan cara meminimalkan pajak sedemikian rupa sehingga utang pajak berapa di posisi paling minimal. Cara ini dilegalkan oleh pemerintah dan berguna bagi perusahaan untuk menekan biaya pajak yang harus dibayarkan.

\section{Pengaruh Leverage terhadap Transfer Pricing}

Leverage diproksikan dengan Debt Equity Ration (DER) secara parsial berpengaruh positif terhadap transfer pricing. Hasil penelitian ini sama dengan hasil penelitian terdahulu yang dilakukan Merle, Al-Gamrh, \& Merle, Al-Gamrh, \& Ahsan (Merle et al., 2019); Richardson \& Lanis (Richardson \& Lanis, 2007); Taylor, Richardson, \& Lanis (Taylor et al., 2015) yang membuktikan bahwa leverage berpengaruh positif dan signifikan terhadap beban pajak perusahaan. Dalam penelitian Richardson \& Lanis (Richardson \& Lanis, 2007) dinyatakan bahwa semakin banyak perusahaan yang membiayai dirinya sendiri dengan hutang, maka semakin rendah beban pajaknya. Oleh karena itu, leverage dapat digunakan untuk mengurangi pajak yang dibayarkan melalui biaya bunga yang tinggi, laba yang lebih rendah, dan ETR yang lebih rendah. Apriani, Putri, \& Umiyati (Apriani et 
al., 2020) mengungkapkan dalam hasil penelitiannya jika leverage berpengaruh positif terhadap keputusan penerapan transfer pricing dalam perusahaan. Hal tersebut diakibatkan karena leverage bisa menjadi faktor yang mendorong keagresivitasan keputusan penerapan transfer pricing dengan tujuan mengurangi beban pajak perusahaan. Hal serupa juga dikemukakan oleh Nabila, Widiastuti, \& Aswar (Nabila et al., 2018) yang dalam penelitiannya dinyatakan bahwa leverage perusahaan berpengaruh terhadap praktik transfer pricing, yang diproksikan dengan 2 (dua) model dalam pengujiannya.

\section{Simpulan dan Saran}

\section{Simpulan}

Data penelitian 12 perusahaan manufaktur yang terdaftar di BEI tahun 2015-2019, memperoleh hasil yang memperlihatkan ada pengaruh signifikan secara serempak antara aset tidak berwujud, ukuran perusahaan, kepatuhan perpajakan, dan leverage terhadap praktik transfer pricing. Aset tidak berwujud dan leverage secara parsial berpengaruh positif dan signifikan terhadap transfer pricing. Namun, ukuran perusahaan secara parsial berpengaruh negatif dan signifikan terhadap transfer pricing. Sedangkan, kepatuhan perpajakan tidak berpengaruh signifikan terhadap transfer pricing.

Sebagaimana penelitian lainnya, maka hal ini juga mempunyai keterbatasan, salah satunya adalah ukuran sampel yang kecil, sehingga tidak memungkinkan dalam mengeksplorasi hasil penelitian secara keseluruhan terhadap perusahaan di BEI. Selain itu, sampel tersebut belum dapat dipastikan apakah anak atau cabang perusahaan yang dimiliki di luar negeri memiliki tarif pajak yang lebih kecil atau tidak.

\section{Saran}

Penelitian selanjutnya harus mengkaji multinasionalitas dan pemanfaatan tax havens sebagaimana secara empiris menunjukkan bahwa faktor-faktor tersebut secara positif terkait dengan intensitas transfer pricing (Taylor et al., 2015).

Implikasi penelitian ini antara lain menunjukkan bahwa secara literatur transfer pricing masih merupakan praktek dan gejala umum pada perusahaan multinasional. Secara praktik perlu adanya terobosan dari pihak otoritas perpajakan agar praktik transfer pricing bisa diminimalisir.

\section{Daftar Pustaka}

Apriani, N., Putri, T. E., \& Umiyati, I. (2020). The Effect of Tax Avoidation, Exchange Rate, Profitability, Leverage, Tunneling Incentive and Intangible Assets on the Decision To Transfer Pricing. JASS (Journal of Accounting for Sustainable Society), 2(2), 14-27.

Arianandini, P. W., \& Ramantha, I. W. (2018). Pengaruh Profitabilitas, Leverage, dan Kepemilikan Institusional pada Tax Avoidance. EJurnal Akuntansi Universitas Udayana, 22(3), 2088-2116.

https://doi.org/https://doi.org/10.2484 3/EJA.2018.v22.i03.p17

Baiti, N., \& Suryani. (2020). Pengaruh Effective Tax Rate, Tunneling Incentive, Exchange Rate dan Mekanisme Bonus pada Keputusan Transfer Pricing Perusahaan. 9(2), 109-120.

Baldenius, T. (2006). Discussion of "Divisional performance measurement and transfer pricing for intangible assets." Review of Accounting Studies, 11(2-3), 
367-376.

https://doi.org/10.1007/s11142-0069000-5

Barford, V., \& Holt, G. (2013). Google, Amazon, Starbucks: The rise of 'tax shaming.' BBC News Magazine 21.

Chaizi, N. (2014). Reformasi Administrasi Publik: Teori dan Praktik. In Jakarta: Grafindo.

Cledy, H., \& Amin, M. N. (2020). Pengaruh Pajak, Ukuran Perusahaan, Profitabilitas, dan Leverage terhadap Keputusan Perusahaa Untuk Melakukan Transfer Pricing. Jurnal Akuntansi Trisakti, 7(2), 247-264. https://doi.org/http://dx.doi.org/10.2 5 105/jat.v7i2.7454

Darussalam, Septriadi, D., \& Kristiaji, B. B. (2013). Transfer Pricing Ide, Strategi, Dan Panduan Praktis Dalam Perspektif Pajak Internasional. In DDTC.

Dischinger, M., \& Riedel, N. (2011). Corporate taxes and the location of intangible assets within multinational firms. Journal of Public Economics, 95(7-8).

https://doi.org/10.1016/j.jpubeco.201 0.12 .002

Dudar, O., Spengel, C., \& Voget, J. (2015). The Impact of Taxes on Bilateral Royalty Flows. ZEW-Centre for European Economic Research Discussion Paper, (15-52). https://doi.org/10.2139/ssrn.2641756

Dyreng, S. D., Hanlon, M., Maydew, E. L., \& Thornock, J. R. (2017). Changes in Corporate Effective Tax Rates Over the Past 25 Years. Journal of Financial Economics, 124(3), 441463.

https://doi.org/10.1016/j.jfineco.201 7. 04.001

Fama, E. F. (1980). Agency Problems and the Theory of the Firm. Journal of Political Economy, 88(2), 288-307. https://doi.org/10.1086/260866
Firmansyah, A., \& Yunidar, A. (2020). Financial Derivatives, Financial Leverage, Intangible Assets, and Transfer Pricing Aggressiveness: Evidence from Indonesian Companies. Jurnal Dinamika Akuntansi Dan Bisnis, 7(1), $\quad 1-14$. https://doi.org/10.24815/jdab.v7i1.1 5334

Hery. (2017). Kajian Riset Akuntansi. Jakarta: PT Grasindo.

Horngren, C. T., Sratton, W. O., \& Sundem, G. L. (1996). Introduction to Management Accounting. New Jersey: Prenctice Hall International Inc.

Indriaswari, Y. N., \& Aprillia, R. (2017). The influence of tax, tunneling incentive, and bonus mechanisms on transfer pricing decision in manufacturing companies. The Indonesian Accounting Review, 7(1), 69-78.

https://doi.org/10.14414/tiar.v7i1.957

Jensen, M. C., \& Meckling, W. H. (1976). Theory of the firm: Managerial behavior, agency costs and ownership structure. Journal of Finance Economic, 3, 305360.

https://doi.org/10.1177/0018726718 812602

Kasmir. (2008). Analisis Laporan Keuangan. Jakarta: Raja Grafindo Persada.

Khotimah, S. K. (2018). Pengaruh Beban Pajak, Tunneling Incentive, dan Ukuran Perusahaan terhadap Keputusan Perusahaan dalam Melakukan Transfer Pricing (Studi Empiris pada Perusahaan Multinasional yang Listing di Bursa Efek Indonesia tahun 2013-2017). Jurnal Ekobis Dewantara, 1(12), 125-138. https://jurnalfe.ustjogja.ac.id/index.p h p/ekobis/article/view/787 
Kiswanto, N., \& Purwaningsih, A. (2015). Pengaruh Pajak, Kepemilikan Asing, dan Ukuran Perusahaan terhadap Transfer Pricing pada Perusahaan Manufaktur di Bei Tahun 2010-2013. Jurnal Ekonomi Akuntansi Universitas Atma Jaya, 1-15.

Kusuma, H., \& Wijaya, B. (2017). Drivers of the Intensity of Transfer Pricing: An Indonesian Evidence. In Proceedings of the Faculty of Commerce Conference, Cairo University.

Kusumasari, R. D., Fadilah, S., \& Sukarmanto, E. (2018). Pengaruh Pajak , Kepemilikan Asing dan Ukuran Perusahaan terhadap Transfer Pricing ( Studi Empiris pada Perusahaan Manufaktur yang Terdaftar di Bursa Efek Indonesia Periode 2012-2016 ). Prosiding Akuntansi, 4(2), 766-774.

McConnell, J. J., \& Servaes, H. (1995). Equity ownership and the two faces of debt. Journal of Financial Economics, 39(1), 131-157. https://doi.org/10.1016/0304 405X(95)00824-X

Menchaoui, I., Rossignol, J., \& Omri, M. A. (2017). Fiscal management practices and their impact on corporate groups' Fiscal performance. Revista Internacional Administracion \& Finanzas, 9(1), 73-86.

Merle, R., Al-Gamrh, B., \& Ahsan, T. (2019). Tax havens and transfer pricing intensity: Evidence from the French CAC-40 listed firms. Cogent Business and Management, 6(1), $1-13$.

https://doi.org/10.1080/23311975.20 19.1647918

Modigliani, F., \& Miller, M. H. (1958). The cost of capital, corporation finance and the theory of investment. The American Economic Review, 48(3), 261-297.

Nabila, R., Widiastuti, N. P. E., \& Aswar, K. (2018). Dampak Pajak, Tunneling Incentive, Leverage, dan Exchange
Rate Terhadap Perlakuan Transfer Pricing. Journal of Physical Therapy Science, 9(1), 1-11.

OECD. (2010). OECD transfer pricing guidelines for multinational enterprises and tax administrations. Paris.

Putri, V. R., \& Putra, B. I. (2017). Pengaruh Leverage, Profitability, Ukuran Perusahaan Dan Proporsi Kepemilikan Institusional Terhadap Tax Avoidance. Jurnal Ekonomi Manajemen Sumber Daya, 19(1), 1. https://doi.org/10.23917/dayasaing.v $19 \mathrm{i} 1.5100$

Rego, S. O. (2003). Tax-avoidance activities of US multinational corporations. Contemporary Accounting Research, 20(4), 805-833. https://doi.org/10.1506/VANNB7UB-GMFA-9E6W

Richardson, G., \& Lanis, R. (2007). Determinants of the variability in corporate effective tax rates and tax reform: Evidence from Australia. Journal of Accounting and Public Policy, 26(6).

https://doi.org/10.1016/j.jaccpubpol. 2007.10 .003

Richardson, G., Taylor, G., \& Lanis, R. (2013). Determinants of transfer pricing aggressiveness: Empirical evidence from Australian firms. Journal of Contemporary Accounting and Economics, 9(2). https://doi.org/10.1016/j.jcae.2013.0 6. 002

Richardson, Hanlon, D., \& Nethercott, L. J. (1998). Thin Capitalization Rules: An Anglo-American Comparison. International Tax Journal, 24(2), 3666.

Scott, W. R. (2000). Financial Accounting Theory 3rd edition. Toronto: Prentice Hall. 
Jurnal Akuntansi a Volume 13 Nomor 2, November 2021 : 388-401

Supriyanti, S., \& Hidayati, N. (2008). Pengaruh Pengetahuan Pajak dan Persepsi Wajib Pajak Terhadap Kepatuhan Wajib Pajak. Akuntansi Dan Teknologi Informasi,7(1). https://doi.org/10.24123/jati.v7i1.19 32

Taylor, G., Richardson, G., \& Lanis, R. (2015). Multinationality, tax havens, intangible assets, and transfer pricing aggressiveness: An empirical analysis. Journal of International Accounting Research, 14(1). https://doi.org/10.2308/jiar-51019 